\title{
O CONTRAPONTO DO JUS NATURALISMO E O JUS POSITIVISMO NA OBRA ANTÍGONA DE SÓFOCLES
}

\author{
Adriano Carvalho Viana* \\ Otávio Roberto Martins Júnior** \\ adrianocrsp@gmail.com
}

Nas cidades antigas, a lei atingia os grandes culpados com um castigo considerado terrível, a privação da sepultura. Punia-se assim a própria alma, e lhe infligiam um suplício quase eterno. (COULANGES, 2009, p.27).

SÓFOCLES, 496-406. Édipo Rei; Antígona/ Sófocles; tradução Ordep Serra e Sueli de Regino São Paulo: Martin Claret, 2017. - (Coleção a obra-prima de cada autor). Ordep José Trindade Serra é Pós-Doutorado em Literatura e Cultura pela Universidade Federal da Bahia. Professor Aposentado do Departamento de Antropologia da Faculdade de Filosofia e Ciências Humanas da Universidade Federal da Bahia. Membro da Academia de Letras da Bahia. Realizou a tradução do Livro Sófocles para a editora Martin Claret, que se compõe de 250 páginas. Tratase de um clássico da Antiguíssima Grécia, escrito pelo teatrólogo Sófocles.

Sobre Sófocles, chegou até nós uma biografia anônima, a única que nos restou dentre as muitas escritas na Antiguidade, há um relato curioso, que tem todo o jeito de conter um arranjo. Diz-se aí que Eurípides nasceu no dia da celebração da vitória ateniense de Salamina (480 a.C.), batalha naval que Ésquilo combateu. Nessa festa, de acordo com a mesma fonte, o jovem Sófocles (então com dezessete anos) estava à frente do coro dos moços, tocando a lira e entoando a peã triunfal. $\mathrm{O}$ sincronismo terá sido fabricado, mas a anedota tem a vantagem de chamar a atenção, de uma bela maneira, para o entrecruzar-se das vidas dos três grandes trágicos num cenário denso de sentido histórico. A Vita Sophoclis ${ }^{1}$.

Na obra de Sófocles, há uma compreensão muito profunda do sofrimento. Sua poesia também sugere uma rara solidão interior - alimentada, quiçá, por sua luz. O citado helenista holandês, Opstelten, bem o viu: "reflete-se aí um poder de harmonia que não faz pensar numa tranquilidade idílica" (grifo nosso), antes, sugere o vigor de uma alma capaz de reconstituir seu equilíbrio temperando-se, dinamicamente, com o próprio ímpeto da paixão". Conforme diz ainda Opstelten (2017, p. 84).

\footnotetext{
* Graduado em Filosofia, pelo Centro Universitário Assunção- UNIFAI. Graduando em Direito pela Faculdade Santa Terezinha-CEST. Graduando em Teologia pela Faculdade - UNINTER. Mestrando em Letras pela Universidade Federal do Maranhão.

** Graduando em Direito pela Faculdade Santa Terezinha-CEST. Pesquisador na área de Direito Penal.
} 
Percebe-se em Sófocles um pendor para a melancolia, mas com um toque positivo: esta parece brotar do élan amoroso que tornava profunda sua compaixão e também tinha a ver com sua sede de conhecimento, seu desejo de compreender. Assim é. Mostra-o a forma como os heróis sofoclianos reagem às crises, aos conflitos em que penetram: ativamente, com uma profunda vibração interior, espiritual. E importa aqui salientar a figura de Antígona, a musa de nossa dissertação, que contém um pano de fundo necessário para algumas temáticas relevantes. Os acadêmicos de direito ao adentrar no curso são orientados a ler a obra se quiserem obter respostas para algumas questões que surgirão ao longo do curso. Por exemplo: será que aquele que luta contra a sua Cidade-Estado (pólis) é digno de honras? Será que aquele que luta contra o Soberano, se faz necessário prestar-lhe as apropriadas celebrações fúnebres? O paradoxo se fixa em dois contrapontos: o direito natural e o direito positivado. Mencionam-se aqui dois paralelos: a pátria e a escravidão.

Sófocles em suas tragédias elenca o sofrimento humano incide tanto sobre o inocente como sobre o culpado; logo, aquele que sofre não é automaticamente culpado, ou seja, na obra de Sófocles "não encontramos teodiceia alguma, nenhuma investigação sobre a causa do sofrimento, mas sim a convicção de que o sofrimento é inerente à natureza humana ${ }^{2} "$.

A filosofia sempre se utilizou de axiologias para se chegar a um denominado fator comum. A lei foi promulgada logo depois de derrubado um dos irmãos vencidos. A tragédia grega acentua as noções de jusnaturalismo e positivismo jurídico, enfatiza o "rei” soberano que impõe sua égide em contraponto ao direito à dignidade da pessoa humana.

Os acadêmicos do curso de Direito se indagam sobre o jus naturalismo e o jus positivismo, porque seu contexto traz duas definições preestabelecidas: os direitos humanos, ou seja, os direitos anteriores são os direitos naturais; e os direitos fundamentais. que são os positivados pelo racionalismo.

Faz-se aqui uma alusão ao jusnaturalismo tradicional (ontológico) ${ }^{3}$, em que os direitos naturais são inerentes a todos os seres humanos: imutáveis, universais e irrevogáveis. O jusnaturalismo axiológico (aquele que defende a ideia de uma ordem de valores per si) é o da ordem eterna, isto é, os valores existentes a priori, anteriores e independentes. Por sua vez, o

\footnotetext{
${ }^{2}$ Opstelten, op. Cit. pp 49 e 50. Cf. ainda ibidem p.96: ““‘... o que nos impressiona em Sófocles é a sua dedicada atenção e sua simpatia profunda para com o sofrimento individual, e em particular para com o sofrimento do inocente..."

${ }^{3}$ A primeira especulação Martin Heidegger, puramente ontológica, é dirigida para a solução do problema do ser. Segundo Heidegger, a compreensão do ser é ao mesmo tempo uma determinação do ser do homem. O homem é a porta de acesso ao ser. Aqui Heidegger aplica o método fenomenológico: parte do homem de fato deixa que ele se manifeste tal qual é, e procura compreender sua manifestação.
} 
jusnaturalismo se torna inerente à condição humana. Por sua existência o ser (daisen) ${ }^{4}$ tem vários direitos. O contraponto é justamente a coletividade do ser humano, um ser de direitos, porém, direitos impostos pelo Estado.

Isto é o jusnaturalismo; é onde os direitos se tornam inerentes à condição humana, por sua existência o ser (daisen) ${ }^{5}$ têm vários direitos. E em contraponto a coletividade como fonte do direito imposto pelo Estado, o ser humano é um sujeito de direitos.

Adentremos na obra para compreensão do contexto: dois irmãos lutam pelo trono de seu Pai. O Primeiro, Polenices, lutou para que a cidade (pólis) ficasse livre do seu Tio Creonte, que almejava o trono; o segundo, Éteocles, lutava para que o tio ocupasse o trono. Na sua luta pelo direito à vida, natural e o direito ao trono, ambos morreram.

Por sua vez, Antígona, sua irmã, sofreu com o falecimento dos irmãos. Como a tragédia não se resumisse só a batalha, Creonte acabou assumindo o trono, e decreta em forma de lei (por sua vez, a lei é um conhecimento, e não cabe aqui fazer juízos axiológicos) que nenhum cidadão ousasse sepultar Polenices, mas sepultasse Éteocles de acordo com as leis e costumes.

Nota-se que Creonte era o Rei gozando de plenos poderes ao declamar sua soberania através da lei, numa espécie de autoritarismo. O paralelo a isso é que séculos depois o Filósofo Thomás Hobbes postula que "os súditos deveriam abrir mão de seu direito em benefício do Rei”, conceito esse que é uma das correntes do jusnaturalismo.

No contexto da cidade Atenas, o direito de proteger as pessoas é favorecido pelo rei Creonte. As leis que ele impõe são engrandecidas e estas ordens recaem sobre os filhos de Édipo. Éteocles, que morreu lutando pelo polis, defendendo-a bravamente com sua lança, será enterrado com ritos fúnebres, tal como os mortos ilustres. Polenices, como destratou da pátria, não receberá sepultura e nem lágrimas e seu cadáver permanecerá exposto para as aves e cães, um horrível espetáculo para os olhos. Creonte, agora Rei de Tebas, personifica a tirania ao apropriar-se das leis escritas em benefício próprio, uma vez que sua intenção é manter-se no poder. Justifica e legitima seus atos quando se prende ferreamente à "manipulável" lei dos homens (Diké): a um desertor, traidor (Polenices), não se permite sepultamento. Isso significa ter seu cadáver jogado aos cães, dilacerado por feras carniceiras e aves de rapina.

Por Zeus, muito mais preocupante que a morte em si, pois esta é certa, é a honra da sepultura, o justo merecimento de, tendo sido bem-quisto neste mundo, obter a glória de ser

\footnotetext{
${ }^{4}$ O primeiro existencial é o ser-no-mundo que se encontra em situação (chamado de Daisen ser-em-situação, por Heidegger), num círculo de afeto e interesses; o homem que está sempre aberto para se tornar algo novo. A própria situação presente é determina por aquilo que ele pretende fazer no futuro: muito do que ele faz hoje, senão tudo, ele o faz em vista do que ele quer ser amanhã.
} 
bem recebido no outro. As leis foram impostas para que Polenices não pudesse ter um funeral condigno, pagar a moeda ao barqueiro Caronte, fazer a travessia pelo Léthe, o rio do esquecimento, chegar ao insondável reino dos mortos, onde Plutão e Perséfone imperam no misterioso Hades.

Onde faz morada o embate entre Thémis e Diké? O conflito jaz em olvidar o telos (propósito, finalidade) da lei em prol da letra que beneficia a quem a aplica, mas "a letra não está acima do espírito da lei dos homens". Quando se confrontam a Lei dos Deuses e a Lei dos Homens? Quando não se atinge sua consonância, quando esta última impõe-se desconsiderando a primeira. Dito de outra forma, dá-se, assim, quando na terra não é como no céu.

O drama de Antígona não consiste na dúvida sobre qual lei seguir. Ela possui envergadura demais para não fugir às consequências, pois, como nos diz Sófocles, "evidenciase a linhagem da donzela, indômita, de pai indômito: não cede nem no momento de enfrentar a adversidade".

Todo corajoso herói domina phobos (medo) - considerado pelos gregos um temido "ente", quase real, que acomete e faz debandar aterrorizados guerreiros, outrora bravos e valentes, diante da batalha. Antígona, destemida, ousada e indomável, atreve-se a desafiar a tirania de seu tio Creonte mesmo ciente da pena de morte que seu ato implicaria. Como observa a sua temerosa irmã Ismene: "ferve diante do que faz gelar", explicitando a recusa de Antígona em obedecer as leis civis.

Antígona, que era irmã de Polenices, não se conforma com aquela medida. Considera uma desonra inaceitável não enterrar o irmão. Por isso, em claro descumprimento da ordem de Creonte, resolve realizar todos os ritos fúnebres devidos em favor do morto. Creonte chama a sobrinha para sabatiná-la. O diálogo resultante é uma sinfonia para aqueles que defendem o direito natural. Ei-lo: Após a Sentinela ter descrito todo o ocorrido, Creonte critica e diz: E tu, tu aí que inclinas a cabeça para o chão, vais negar ou confirmar o que ele diz? (435) Antígona: “Confirmo o que fiz. Não o nego, absolutamente". Creonte: "E tu, quero que fales, com poucas palavras, se sabias que isso havia sido proibido por mim". (440). Antígona: "Sabia! Como não saberia? Todos sabiam”. (445) Creonte: “E ainda assim. Ousaste passar por cima da lei”. Antígona in verbis: 
Sim, pois, para mim não foi Zeus quem a decretou, e nem Dike ${ }^{6}$, a que vive entre os deuses de baixo ${ }^{7}$, que deu aos homens semelhantes leis. Os teus decretos não têm o poder de obrigar um mortal a desobedecer às leis dos deuses, pois, embora não escritas, elas são poderosas e imutáveis. Ninguém sabe quando surgiram, mas foram criadas para todo o sempre e não para o passo ou o presente. Não temo o castigo por violar leis cunhadas pelo poder de um homem, mas por desobedecer às leis dos deuses. Sei que estou diante da morte, e como não saberia? Afinal, ela foi anunciada. Mas afirmo que morrer antes do tempo será para mim uma vantagem. Quando alguém carrega, como eu, tantas dores, vê a morte como um ganho, não é verdade? Pois para mim, o destino que tu me reservas não me parece uma desgraça. Mas saber que o corpo do filho de minha mãe permaneceria sem sepultura, isso sim iria me fazer sofrer. E se te parece que agi de forma insana, talvez mais insano seja quem me acusa de insanidade. (Sófocles, 2017, p.46).

Eis, nesse diálogo, com algumas licenças poéticas, um bom exemplo do sentimento de indignação que surge toda vez que o ordenamento jurídico encontra-se fora de sintonia com o espírito de justiça presente na sociedade. Por isso, costuma-se dizer que a resposta de Antígona é uma das mais remotas defesas do direito natural.

No entanto, há outro diálogo, na mesma peça, que não é citado nos livros de introdução ao direito, que demonstra que o grande vitorioso desse embate entre direito positivo autoritário versus direito natural não foi nem um nem outro. Quem venceu foi o direito democrático.

O outro diálogo foi travado entre Creonte e Hémon, seu filho. Hémon, de forma até meio petulante, questiona a ordem do pai. O pai não arreda pé: disse que o que decidiu está decidido e ponto final. Antígona, portanto, deveria ser punida, conforme previsto na sua ordem. Eis um trecho do diálogo:

Creonte: Não está Antígona violando a lei”?

Hémon: O povo de Tebas não concorda com você.

Creonte: Querias que a cidade me dissesse que ordens devo dar?

Hémon: Agora é você que fala como um menino. [Pouco antes, Creonte havia perguntado se cabia a seu filho ensinar-lhe sabedoria.]

Creonte: Deverei reinar conforme julgam os outros ou segundo meu próprio discernimento?

Hémon: Uma pólis governada por um só homem não é uma pólis.

Creonte: Então o Estado não pertence àquele que o governa? (Sófocles, 2017, p. 38).

Sob o aspecto histórico, o denominado "direito natural" foi engendrado como meio de resistência ao poder político, embora tenha, paradoxalmente, também servido para reforçá-lo.

\footnotetext{
${ }^{6}$ Em Hesíodo, Díke, a Justiça, é uma das Horas, filhas de Zeus e da deusa Têmis. As outras irmãs são: Eunômia, a Disciplina, e Irene, a Paz. Díke representa a Justiça dos homens, as leis e os julgamentos.

${ }^{7}$ Os "deuses de baixo", aos quais se refere a personagem, são os deuses do mundo inferior, que viviam abaixo da superfície da terra. Hesíodo descreve esses mundos subterrâneos divididos em três partes: o Tártaro, o Érebo e o Hades. O local mais profundo era o Tártaro, onde ficavam as mansões dos deuses ctõnicos, abaixo do Érebo e do Hades, regiões dominadas pelo deus Hades.
} 
Desde Antígona, passando pelos estóicos e Cícero até Tomás de Aquino, procurou-se sustentar a dualidade de um superdireito e do direito positivo. O primeiro, por ser comum a todo homem, tinha caráter transcendental, por isso, pairaria acima do jus positum de cada Estado. O segundo, o direito positivo, por lhe ser inferior, devia com ele se conformar. Mas, a doutrina do "direito natural" também serviu para justificar e manter autocracias laicas e teocráticas, pois tudo que o ditador ou o "homem de Deus" fazia era em obediência a princípios superiores, que se achavam acima dos homens e se destinavam ao bem comum. Daí Kant (1724-1804) ter um pouco de Antígona e de Direito Natural, procurando harmonizar o direito natural e o direito positivo, numa relação de integração, e não de antítese.

Portanto, ao observamos as questões do positivismo jurídico no enredo, vemos que Creonte utilizou o poder do estado para alegar omissão com relação à Polenices, porque estava positivado segundo as leis de Tebas. Entretanto, se notarmos no contexto histórico já trazendo para o século XX foi o mesmo argumento utilizado por Hitler na segunda guerra mundial para dizimar metade da população judaica da Europa.

“Todavia, o positivismo nega em princípio a existência de juízos de valor, pois se prende exclusivamente aos fenômenos que podem ser observados". Faz apenas juízos de constatação. Desse modo, a lei é guindada à posição de valor único. Portanto, Creonte utilizou o poder estatal para que não fossem malquistos perante seus subordinados. Porque, segundo a obra de Nicolau Maquiavel, "é melhor ser temido, do quer ser amado" (Maquiavel, 2011, p.20).

Nisso Kelsen engendrou a teoria pura do Direito desprovido de emotivíssimos, do pensamento mais íntimo, dos valores, enfim. Todas essas teorias naufragaram a partir da metade do século XX pelo seu hermetismo e aspereza e pelo fato de colocar em plano esquecido a natureza humana. A natureza de tal conceito nos leva a crer que Creonte estava bem convicto do que fez e só não esperava o fim trágico que levou a todos.

Portanto, se percebermos o conceito real e a natureza dos positivismos, notaremos que Creonte foi sábio em sua decisão, pois, caso viessem a acontecer novos casos de revoltas, se faria necessário o uso do mecanismo do estado para se fazer cumprir a lei, a saber, o direito positivo objetivando atingir os fins de justiça.

Conclui-se que, na obra, o positivismo jurídico se sobrepôs ao jus naturalismo, como já exposto no desenvolvimento do enredo. Creonte agiu de forma correta, pois qualquer atitude colocaria a situação dentro do texto de uma desobediência ao poder positivado. No impasse se sobressaíram as normas, porque, se notarmos as ações de Creonte, evidencia-se que ele se utilizou do poder estatal para estabelecer a ordem em Tebas. 


\section{Referências Bibliográficas}

COULANGES, Fustel. A cidade antiga: estudo sobre o culto, o direito e as instituições de Grécia e de Roma. São Paulo: Martin Claret, 2009.

HART, H. 1. A. O conceito de direito. São Paulo: Martins Fontes, 2009.

HEIDEGGER, M. Ser e tempo. Tradução de Marcia Sá Cavalcante Schuback. Petrópolis: Vozes, 2002.

HEIDEGGER, Martin. A essência da linguagem. In: A caminho da linguagem. Trad. Márcia de Sá Cavalcante Schuback. Petrópolis: Vozes, 2003.

LOCKE, John. Segundo tratado sobre o governo. São Paulo: Martin Claret, 2010.

OPSTELTEN, Sophocles and Greek Pessimism, Amsterdam, 1952.

SÓFOCLES. Antígona. São Paulo: Martin Claret, 2017. 